\section{Philosophy of Science}

AT a meeting held at University College, London, on June 1, a Philosophy of Science Group was formally constituted and affiliated with the British Society for the History of Science. The Group adopted the following statement of aims: "The purpose of the Group is to study the logic and method of science as well as of the various special sciences, including the social sciences. The main emphasis is upon an approach through the various special sciences to the philosophy of science." The Group intends to hold meetings for the reading and discussion of papers and to publish an account of its activities in a supplement to the Bulletin of the British Society for the History of Science, which will be circulated to members. The Group has elected the following Committee : Prof. H. Dingle (chairman), Dr. K. R. Popper, Mr. F. I. G. Rawlins, Dr. G. J. Whitrow and Dr. A. C. Crombie (honorary secretary), Department of History and Philosophy of Science, University College, Gower Street, London, W.C.1. It is hoped to hold the first ordinary meeting in the autumn of this year.

\section{Conference on Noise and Sound Transmission}

THE Acoustics Group of the Physical Society, in association with the Royal Institute of British Architects, is holding a three-day International Conference on Noise and Sound Transmission during July 14-16. This is the first major international discussion of the subject for many years, and papers will be read by European and American investigators in addition to the contributions from Great Britain. Among those reading papers are L. L. Beranek (United States) ; T. Vogel, R. Lehmann, P. Chavasse, F. Canac (France); W. Fürrer (Switzerland); W. K. Westmijze, C. W. Kosten, J. van den Eijk (Holland); F. Ingerslev, V. L. Jordan, P. V. Bruel (Denmark); E. Meyer, A. Schoch, L. Cremer (Germany); N. Fleming, R. S. Dadson, H. L. Kirke, W. A. Allen and A. J. King (Great Britain). The papers will cover the subjects of sound insulation in buildings, aircraft and ships; impact sound; resilient suspension systems; proposals for standardization of measurement, and the measurement of noise. Those who desire to have copies of summaries of papers in advance of the meetings should send requests to the Joint Honorary Secretaries of the Acousties Group at 1 Lowther Gardens, Prince Consort Road, London, S.W.7.

\section{International Congress of Industrial Medicine}

THE ninth International Congress of Industrial Medicine will be held in London, at the Caxton Hall, during September 13-17. The last congress was held in Frankfurt in 1938. The congress will meet in six sections devoted respectively to social aspects, environment, nursing, clinical studies, practice and legal and miscellaneous topics. Among the subjects announced for discussion are incentives, work and skill, dust hazards, pneumokoniosis, physical, biological and psychological effects of environment, effects of working with the newer chemicals and metals, hazards of radiant energy, etc. Further particulars can be obtained from the secretary of the Congress, Room 501, Garden Court Wing, B.M.A. House, Tavistock Square, London, W.C.1.

\section{Congress on Biological Chemistry}

THe Société de Chimie Biologique will hold its eighth congress in Paris during October 6-8. This will be the first international congress on the subject in France for ten years, the previous meeting having been held at Liège in 1946. Subjects for special consideration at the Paris congress are: proteins and hormones (reports by Profs. Theorell and Fromageot) ; biological organic chemistry and plant biochemistry (reports by Profs. Stoll and Janot); vitamins and hormones (reports by Profs. E. C. Dodds and Horeau). Sessions will also be reserved for communications outside these subjects, and provision will be made for experimental demonstrations. Further particulars can be obtained from the secretary-general of the congress, $M$. Jean Courtois, 4 Avenue de l'Observatoire, Paris, VIe

\section{Science and Industrial Practice in the Iron and Steel Industry}

THE British Iron and Steel Research Association is arranging two conferences to be held next autumn at Ashorne Hill, nr. Leamington. The first, in which the Institute of Physics is also interested, will be held on September 8 and 9, and is to discuss nondestructive testing of castings. Three sessions will be arranged to discuss papers on $\mathrm{X}$ - and gamma-ray methods and on $\mathrm{X}$-ray equipment, radioactive materials and radiography abroad; magnetic and ultrasonic methods; recent work by the Non. Destructive Testing Sub-Committee of the Association on the comparison of X-ray, gamma-ray and ultrasonic methods, and a paper on acceptance standards. It is intended that the papers shall deal essentially with the practical aspects of the subject and be of interest to executives not conversant with the methods, but who might be considering their use. The second conference is planned for October 21 and 22 , and is to discuss foundry core bonding agents. The object is to bring to the notice of founders the wealth of information that has been obtained in recent years on the new materials that may be used for the bonding of foundry cores. The use of such materials, in many cases with an appreciable reduction in cost, would enable the linseed oil used hitherto to be diverted to alleviate the shortage of edible fats. There will again be three sessions: natural resources of the materials, recent work by the Association on the practical and fundamental aspects of bonding, and the properties of new materials such as plastics and petroleum products; experience of founders with such materials; and the impact of these materials on matters such as core-blowing, and dielectric and infra-red heating.

\section{International Scientific Film Congress}

THE second congress of the International Scientific Film Association will be held in London during October 4-11. It is being convened by the Scientific Film Association of Great Britain, with the help of the British Film Institute. Three days will be devoted to business meetings of the Association, and three days to a festival of scientific films, when it is hoped to show many contributions from all the participating countries to members of the general public. The congress will close with a general assembly of the delegates on October 11. The Association was constituted last year in Paris by delegates from twenty-two countries who had accepted the joint invitation to the inaugural congress from the Scientific Film Associations of Great Britain and France. The primary aim of the Association is: "To raise the standard and to promote the use of the scientific film and related material throughout the world in order to achieve the widest possible understanding 